1134

\title{
気流中に置かれた三次元台状物体の表面上を移動する 液滴群の数值シミュレーション*
}

\author{
土 井 克 則*1, 川 鍋 健*2 \\ 濱 本 直 樹*3, 中 村 佳 朗*1
}

\section{Numerical Simulation of Droplets Moving on Surface of Three-Dimensional Trapezoidal Object in Air Flow}

\author{
Katsunori DOI*4, Takeshi KAWANABE, \\ Naoki HAMAMOTO and Yoshiaki NAKAMURA \\ *4 Department of Aerospace Engineering, Nagoya University, \\ Furo-cho, Chikusa-ku, Nagoya-shi, Aichi, 464-8603 Japan
}

\begin{abstract}
In this study, we numerically simulated behavior of droplets moving on a surface of a solid threedimensional trapezoidal object exposed to air flow. This condition can be related to a case that an automobile runs in the rain. The Lagrangian model was applied to the droplets, where motion of each droplet was tracked in the simulation. Aerodynamic drag force, adhesion force, viscous friction, and gravity on the droplet were considered, and parameters in their model were identified by results of some elemental experiments. And, size distribution and coalescence of droplets were also considered. In the results, larger droplets grown by their coalescences climbed up on the front face of the object, and some droplets were collected on a region of the side face where there was a vortex generated by flow separation from the edge of the front face. These phenomena were similar to those observed in experiments.
\end{abstract}

Key Words: Droplets, Wetting, Gas-Liquid Two-Phase Flow, Numerical Simulation, Automobile, Rain

\section{1. 緒言}

固体表面に付着した液滴群が，重力や空気力によっ て，その表面上を移動する現象は，我々の身近に数多 く存在する. しかし，その力学的機構の詳細は非常に 複雑である. 液滴が接触する固体表面および周囲の気 体との界面にはたらく相互作用によって, 各液滴はそ の内部を流動させながら, 運動, 変形, 合体, 分裂し, 時には液膜や小川のような様相を示す。

このような現象の一例として, 雨天走行時の自動車 に付着する雨水が挙げられる。 フロントウインドに付 着した雨水は，運転者の前方視界を妨げると共に，そ の一部はサイドウインドに移動して，側方視界およ びサイドミラーを介した間接後方視界を妨げる．従っ て，運転者の周囲視認性を確保するためには，表面の 形状や濡れ性の調整，あるいは，ワイパ等の除去装置 によって，雨水を制御する必要がある，例えば，中川 ら (1) は，サイドウインド上の雨水を実験で観察し，車 速の違いやサイドミラーの有無によって，その状態が

* 原稿受付 2009 年 12 月 28 日。

*1 正員, 名古屋大学工学部 (业 464-8603 名古屋市千種区不老 町).

*2 名古屋大学大学院工学研究科.

*3 三菱自動車工業 (株) (可 444-8501 阙崎市橋目町字中親切 1).

E-mail : doi@nuae.nagoya-u.ac.jp
大きく異なることを示した，この結果は，車体形状に 依る気流を調整することで雨水の状態を制御できる可 能性を示唆する。

また，自動車に付着する雨水は車体の污れの原因と なる．例えば，知名ら ${ }^{(2)}$ は，車体周り流れ場の数值シ ミュレーションによって得られた気流の速度場を用い て，水滴を含む活れ粒子の運動を予測した．具体的に は，個々の粒子の運動を追跡する方法（污れ粒子追跡 法）や粒子群の運動を模擬する移流拡散方程式を解く 方法 (污れ濃度法) によって数值的に予測し，その結 果は実験結果を良く再現した。しかし，これらの方法 は車体に付着するまでの予測に限られる.

このように，自動車に付着する雨水に関して。その 必要性から多くの解析やその手法の提案がなされてい る. しかし，実際の自動車開発においては，空力性能 や騒音特性，あるいは意匠性などを含めた総合的な検 討を迅速に行う必要があり，その要求を満たすような 高精度で簡易な予測手段の確立には至っていない。

自動車に付着する雨水の他にも, 固体表面に付着し た液滴の運動に関して，様々な現象が解析されている。 例えば, Nakajima et al. ${ }^{(3)}$ は, 表面の動的撥水性の評価 として，撥水処理を施した斜面上に置かれた液滴の転 落現象を高速度カメラによって詳細に計測し，その運 
動の特性を示した. また, Zhang et al. ${ }^{(4)}$ は, 燃料電池 の発電に伴って発生する水滴が流路内で滞留して発電 効率を低減させる現象を観察し，液滴が気流によって 排除される条件を明らかにした．しかし，これらの現 象を支配する基本的な力学的構造については，依然と して末解明な点が多い.

一方, 液滴群の状態を予測する手段としては，DDM (Discrete Droplet Model) 法 ${ }^{(5)}$ が知られており，主に液 体燃料噴霧の解析に適用されている。この手法では一 般的に，ある一群の液滴をパーセルと呼ばれる単位で 报い，その代表液滴の運動をラグランジュ的に追跡す る，これにより，計算量を低減できるが，各パーセル 内における液滴の状態のばらつきや相对運動および液 滴の合体を直接扱うことは出来ず，統計学的なサブモ デルで扱う必要がある．また，液滴が壁面上を移動す るような現象の適切なモデルは確立されていない．

本稿では，固体表面に付着した液滴群が空気力に よって移動する現象を予測する数值シミュレーション の方法を提案する．具体的には，全ての液滴について， その個々を追跡するラグランジュ的手法を用いる．液 滴に作用する力として, 空気力, 付着力, 粘性摩擦力, 重力を考慮する．また，単一液滴の幾何形状や力学的 特性を計測する実験（基本実験）の結果によって，各 作用を評価するモデルを同定する．さらに，液滴の大 きさのばらつきや液滴の合体も考慮する.

そして，提案した方法を用いて，気流にさらされた 物体表面に付着した液滴群の運動を解析する. 図 1 に 解析対象の概要を示す．物体は，直方体をその側面に 垂直な平面で斜めに切断した形状とし，その切断面で ある斜面に気流によって運ばれた液滴群が付着する。 そして, 空気力によって液滴群は物体上面あるいは側 面を伝わりながら下流側へ運ばれる。この解析対象は, 雨天走行中の自動車に雨滴群が付着する状態を想定し ている．このような基本的な現象の解析により，物体 表面に付着した液滴群の運動に関する基本的な知見を 得る。また，同様の条件における液滴群の様子を観測 する実験（検証実験）の結果を計算結果と比較するこ とで, 本シミュレーション方法の妥当性を検証する.

\section{2. 計 算 モ デル}

2.1 液滴の支配方程式本研究では, 液滴群を 構成する各液滴について，並進運動の方程式を個々に 解くことによって運動を計算する。

質量 $m_{p}$ の液滴について，その代表点の位置 $\vec{r}_{p}$ およ び速度 $\vec{v}_{p}$ は，次式から求められる。

$$
\frac{d \vec{r}_{p}}{d t}=\vec{v}_{p}
$$

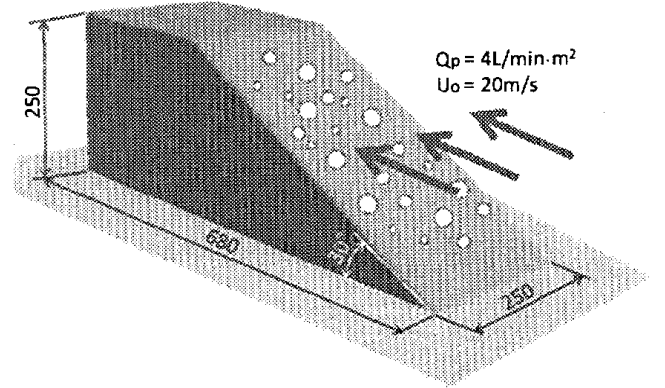

Fig. 1 Droplets on the three-dimensional trapezoidal object in air flow

$$
m_{p} \frac{d \vec{v}_{p}}{d t}=\vec{f}_{n}+\vec{f}_{t}
$$

ここで， $\vec{f}_{n}, \vec{f}_{t}$ は液滴に作用する力であり, 液滴が付 着した物体表面に垂直な方向成分，平行な方向成分を それぞれ表す．液滴の回転運動や変形，液滴内の流動， および，蒸発や浸透による質量の変化は考慮しない。

垂直方向成分 $\vec{f}_{n}$ は，液滴を物体表面に留める拘束 力として作用し，その結果として液滴は常に物体表面 に付着した状態にあると仮定する．また，平行方向成 分 $\vec{f}_{i}$ は，液滴を物体表面上で移動させる面内力とし て作用し，次式で与えられると仮定する.

$$
\vec{f}_{t}=\vec{f}_{G}+\vec{f}_{S}+\vec{f}_{V}+\vec{f}_{A}
$$

ここで, $\vec{f}_{G}, \vec{f}_{S}, \vec{f}_{V}, \vec{f}_{A}$ は, 重力, 付着力, 粘性摩擦 力，空気力の平行方向成分をそれぞれ表す.

重力の平行方向成分 $\vec{f}_{G}$ は, 次式で与えられる.

$$
\vec{f}_{G}=m_{p}\left\{\vec{g}-\left(\vec{g} \cdot \vec{n}_{W}\right) \vec{n}_{W}\right\}
$$

ここで， $\vec{g}$ は重力加速度べクトル， $\vec{n}_{W}$ は物体表面の 外向き法線単位べクトルをそれぞれ表す。面内力の残 りの要素 $\vec{f}_{S}, \vec{f}_{V} ， \vec{f}_{A}$ についても，推定される力学的 構造に基づくモデル（後述）によって与えられる.

2.2 液滴の形状 はじめに, 各面内力要素に大 きく影響を及ぼす液滴の形状を検討する。

図 2 に液滴の形状モデルを示す，液滴の形状は capped sphere（球を物体表面で切断した形状）であ ると仮定する。これは，静止した液滴に一様な表面張 カのみが作用する場合の平衡状態に等しく，概して液 滴が小さいほど本形状に近づく．なお，物体表面の曲 率は考慮せず，液滴の大きさに対して局所的に平面で あると仮定している。

以上の仮定から，質量 $m_{p}$ の液滴と物体表面の接触 面の直径 $D_{p}$ を計算すると, 次式が得られる.

$$
D_{p}=\sqrt[3]{\frac{2 \sin ^{3} \theta}{2-3 \cos \theta+\cos ^{3} \theta} \frac{12}{\pi} \frac{m_{p}}{\rho_{L}}}
$$




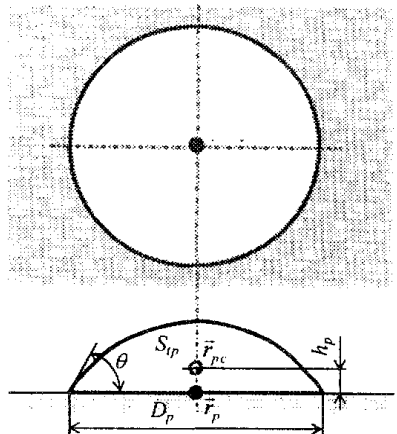

Fig. 2 Shape of a droplet

ここで， $\rho_{L}$ は液滴を組成する液体の密度を表す。ま た, $\theta$ は液滴表面と物体表面が成す角である接触角を 表し，この値は液滴の組成や物体表面の性状に依る。 本研究では，基本実験の結果に基づき，式(5)の仮定 の下で接触角 $\theta$ の值を同定する.

また，液滴の形状に関して，物体表面に垂淔な方向 の投影面積 $S_{n p}$, 平行な方向の投影面積 $S_{i p}$, およびそ の図心の高さ $h_{p}$ は，それぞれ以下の式で与えられる.

$$
\begin{gathered}
S_{n p}=\frac{\pi}{4} D_{p}^{2} \\
S_{t p}=\frac{2 \theta-\sin 2 \theta}{\pi \sin ^{2} \theta} \frac{\pi}{8} D_{p}^{2} \\
h_{p}=\frac{\pi \sin ^{2} \theta}{2 \theta-\sin 2 \theta} \frac{2}{3 \pi} D_{p}
\end{gathered}
$$

2.3 付着力 水平に保持した平面上に液滴を置 いた状態から平面を傾けていくと，その傾斜角が転落 角と呼ばれる所定の值に達するまで，液滴は静止状態 を保持する，この現象は，固体表面間に作用する静止 摩擦力と同様に，液滴を動かそうとする力を打ち消す 逆方向の力が接触面に作用し，かつ，その大きさに上 限值があることを意味する，本研究では，この力を付 着力と呼ぶ。

Wolfram et al ${ }^{(6)}$ は，撥水性表面に置かれた様々な大 きさの液滴の転落角を計測し，付着力が接触面の直径 に比例することを示した。これは，三重線と呼ばれる 液滴表面と物体表面の接触線における表面張力が付着 力に関与していることを示唆する. また, Furmidge ${ }^{(7)}$ は，斜面上の液滴が変形することで, 液滴の斜面上方 側と下方側で接触角に差が生じ，これによる表面張力 の差が付着力として作用するモデルを提案した.

これらの結果に基づき, 付着力の最大值 $f_{S, \text { max }}$ を次 式で与える.

$$
f_{S, \max }=\gamma \pi D_{p}
$$

ここで, $\gamma$ は比例係数であり, 液滴の組成や物体表面 の性状に依る。本研究では, 基本実験の結果に基づき, 式 (9)の仮定の下で係数 $\gamma$ を同定する.
式 (9)で与えられる付着力の最大值に対して, 実際 の付着力 $\vec{f}_{S}$ は以下の様に作用すると仮定する．液滴 が静止しているとき, 他の面内力の総和が最大值未満 である場合には，それを打ち消すように付着力が作用 し，総和が最大值以上である場合には，それと逆方向 に最大値と等しい大きさの付着力が作用する、また， 液滴が移動しているときは，その速度と逆方向に，上 限値と等しい大きさの付着力が作用する.すなおち， 動摩擦力は静止摩擦力に等しいと仮定する.

2.4 粘性摩擦力 転落角以上汇傾いた平面上に 置かれた液滴は，斜面を下りながら加速し，やがて所 定の速度に達する。これは, 液滴の移動速度の増加と 共に大きくなる力が移動速度と逆方向に作用すること を意味する. 本研究では, この力を粘性摩摖力と呼ぶ。

Sakai et al. ${ }^{(8)}$ は, 斜面を下る液滴の運動とその内部 流動を観察し，内部流動を伴い比較的速度の低い“回 転モード”と内部流動が無く比較的速度の高い“滑り モード”の二種類のモードが存在することを示した。 本研究の対象とする現象は液滴の移動速度が比較的高 い場合に相当するため, “滑りモード”で運動する場 合を想定し，液滴内部の物体表面上に形成されたせん 断層の速度勾配による粘性応力が粘性摩擦力として液 滴に作用すると仮定する.

そして, 粘性摩擦力 $\vec{f}_{V}$ を次式で与える.

$$
\vec{f}_{V}=-\mu_{L} S_{n p} \frac{\vec{v}_{p}}{\lambda}
$$

ここで， $\mu_{L}$ は液滴を組成する液体の粘性係数を表す。 また，入はせん断層の厚さに相当する係数である. 本 研究では, 基本実験の結果に基づき, 式 (10)の仮定の 下で係数 $\lambda$ を同定する.

2.5 空気力 気流にさらされた液滴の表面には, 非一様な圧力およびせん断応力が作用する。本研究で は，この合力を空気力と乎ぶ：そして，流体力学の通 例に従い, 空気力を次式で与える。

$$
\vec{f}_{A}=C_{D} S_{n p} \frac{1}{2} \rho_{A}\left|\vec{v}_{r}\right| \vec{v}_{r}
$$

ここで， $\rho_{A}$ は気体の密度を表す．また， $\vec{v}_{r}$ は相対速 度べクトルであり，次式で与えられる。

$$
\vec{v}_{r}=\vec{v}_{A}\left(\vec{r}_{p c}\right)-\vec{v}_{p}
$$

ここで, $\vec{v}_{A}\left(\vec{r}_{p c}\right)$ は気体の代表速度である. 本研究が対 象とする問題では，固体表面上に形成される境界層の 厚さと液滴の高さは同程度であり, 液滴周团の気体速 度分布は一様ではない，そこで，図2 2 示すように, 液滴の代表位置 $\vec{r}_{p}$ の直上で図心高さ $h_{p}$ と等しい高さ の位置を参照位置 $\vec{r}_{p c}$ とし, 液滴が存在しない場合の 参照位置に扔ける気体速度を代表速度とする。 
式(11) の抗力係数 $C_{D}$ は, 液滴レイノルズ数 $R e_{p}$ の 関数として, 以下の関係を纳定する.

$$
C_{D}=C_{D 0} R_{p}^{-m}
$$

ここで, 液滴レイノルズ数 $R e_{p}$ は次式で与えられる.

$$
\operatorname{Re}_{p}=\frac{\rho_{A}\left|\vec{v}_{r}\right| D_{p}}{\mu_{A}}
$$

式中の $\mu_{A}$ は気体の粘性係数を表す.

抗力係数のパラメータ $C_{D 0}, m$ の值は液滴の形状に より変化する. すなわち，これらの値は液滴の形状に 影響を及ぼす液滴の組成や物体表面の性状に依る. 本 研究では, 基本実験の結果に基づき, 式(11) および式 (13) の仮定の下でパラメータ $C_{D 0}, m$ を同定する.

2.6 液滴の合体 二つ以上の液滴が接触すると, 表面張力によって変形して，平衡状態である一つの液 滴を形成する．本研究では，この現象を合体と呼ぶ，

本研究では, 計算モデルを簡単化するために, 合体 に要する時間が液滴の運動の時間スケールに比べては るかに短く, 所定の接触条件を満たした瞬間に変形を 終えると仮定する．また，変形後の形状は変形前と相 似であり, 変形前後で重心の位置が変化せず, かつ, 質量および運動量が保存されると仮定する。

接触条件として, 質量 $m_{p 1}$, 直径 $D_{p 1}$, 位置 $\vec{r}_{p 1}$, 速 度 $\vec{v}_{p 1}$ の液滴 1 と, 質量 $m_{p 2}$, 直径 $D_{p 2}$, 位置 $\vec{r}_{p 2}$, 速度 $\vec{v}_{p 2}$ の液滴 2 が次式を満たすとき, 両液滴は合体する.

$$
\left|\vec{r}_{p 1}-\vec{r}_{p 2}\right| \leq \frac{D_{p 1}+D_{p 2}}{2}
$$

このとき, 合体後の液滴の質量 $m_{p}$, 位置 $\vec{r}_{p}$, 速度 $\vec{v}_{p}$ はそれぞれ以下の式で与えられる.

$$
\begin{gathered}
m_{p}=m_{p 1}+m_{p 2} \\
\vec{r}_{p}=\frac{m_{p 1} \vec{r}_{p 1}+m_{p 2} \vec{r}_{p 2}}{m_{p 1}+m_{p 2}} \\
\vec{v}_{p}=\frac{m_{p 1} \vec{v}_{p 1}+m_{p 2} \vec{v}_{p 2}}{m_{p 1}+m_{p 2}}
\end{gathered}
$$

三つ以上の液滴の合体についても同様に扱う.

2.7 液滴の付着 気流によって運ばれた液滴群 は，次々と物体表面に付着する．本研究では，特定の 物体表面領域で液滴を適切に追加して，この現象を模 擬する，具体的には，液滴の全質量流量扔よび粒径分 布の時間平均が所定の条件值に等しく, かつ, 所定の 物体表面領域内で質量流量の時間平均が一様になるよ うに, ランダムな数および質量の液滴をランダムな位 置に適時追加する.

液滴に作用する力やその運動は液滴の質量や大きさ の違いによって大きく異なるため, 付着する液滴の粒
径分布を考慮する必要がある，本研究では，流入する 液滴の粒径分布がロジン・ラムラー分布 ${ }^{(9)}$ に従うと仮 定する.この分布は, 様々な噴霧液滴の粒径分布を比 較的良く再現することが知られている．このとき，液 滴径 $D$ の質量密度分布関数 $f_{M}(D)$ は次式で表される.

$$
f_{M}(D)=\frac{n}{D_{0}}\left(\frac{D}{D_{0}}\right)^{n-1} \exp \left\{-\left(\frac{D}{D_{0}}\right)^{n}\right\}
$$

ここで， $D_{0}$ および $n$ は分布のパラメータである.

また, 質量密度分布関数 $f_{M}(D)$ は, 次式で表す累積 数分布関数 $F_{N}(D)$ に変換される.

$$
F_{N}(D)=\frac{\int_{D_{\min }}^{D} f_{M}(D) D^{-3} d D}{\int_{D_{\min }}^{D_{\max }} f_{M}(D) D^{-3} d D}
$$

ここで, $D_{\max }, D_{\min }$ は設定した液滴径の最大值, 最小 值をそれぞれ表す．そして，累積数分布関数 $F_{N}(D)$ が 確率変数を $D$ とする確率累積分布関数に等しく, これ に従ってランダムな径の液滴が付着すると仮定する。

2.8 気流の支配方程式 気流は非圧縮粘性流体 とし，その流れ場はナビエ・ストークス方程式に従う。

本研究では, 液滴の存在による体積排除効果および 空気力の反力は考慮しない. また, 気流は定常である と仮定する.これにより, 空気力の評伍精度が若干低 隇する代わりに, 計算方法の大幅な簡素化と計算コス トの大幅な低減を実現できる.

\section{3. 計 算 方 法}

シミュレーション計算の流れを図 3 に示す.

液滴の計算を実行する前に, あらかじめ気流の速度 場を計算しておく. 本研究では, 疑似圧縮性法に基づ き, 陰解法である LU-SGS 法によって定常解を求め る. また, 非粘性項の計算に MUSCL 法, 粘性項に二 次中心差分をそれぞれ用いる. そして, 得られた速度 場 $\vec{v}_{A}(\vec{r})$ を以降の液滴の計算に用いる.

液滴については, 各時間ステップで以下の手順を実 行して各液滴の時間履歴を算出する.

初めに, 式(1) と式 (2)において, 面内力 $\vec{f}_{t}$ のみが 時間刻み分だけ作用した後の位置 $\vec{r}_{p}^{*}$ と速度 $\vec{v}_{p}^{*}$ を計算 する. ここで, 面内力の要素である空気力 $\vec{f}_{A}$ の計算 に, あらかじめ求めた気流の速度場 $\vec{v}_{A}(\vec{r})$ を用いる.

次に, 拘束力 $\vec{f}_{n}$ を考慮する. 本研究では, 拘束力 を直接計算せず，その結果である位置と速度の面内拘 束条件を満たすように, 位置 $\vec{r}_{p}^{*}$ と速度 $\vec{v}_{p}^{*}$ を以下の式 によって補正する.

$$
\begin{gathered}
\vec{r}_{p}=\vec{r}_{p}^{*}-\left\{\left(\vec{r}_{p}^{*}-\vec{r}_{W}\right) \cdot \vec{n}_{W}\right\} \vec{n}_{W} \\
\vec{v}_{p}=\vec{v}_{p}^{*}-\left(\vec{v}_{p}^{*} \cdot \vec{n}_{W}\right) \vec{n}_{W}
\end{gathered}
$$




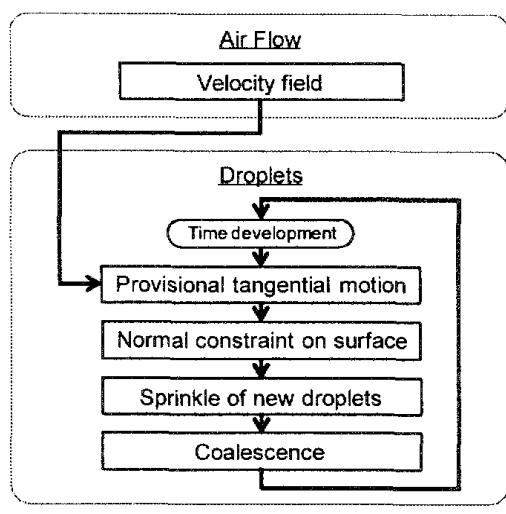

Fig. 3 Flow chart of computation

ここで， $\vec{r}_{W}$ は液滴近傍の物体表面の代表位置を表す。

続いて，液滴の流入条件に心じて物体表面上に液滴 を追加する. 本研究では，追加する液滴の質量 $m_{p}$ を 次式で決定する.

$$
m_{p}=\frac{\pi}{6} \rho_{p}\left\{F_{N}^{-1}(X)\right\}^{3}
$$

ここで， $X$ には $0 \leq X \leq 10$ 範囲で等確率な乱数を与 える，そして，流量の条件に応じた時間刻み当たりの 質量に達するまで、ランダムな質量の液滴を所定の領 域内のランダムな位置に追加することを繰り返す。

最後に, 液滴の合体を考慮する。二つの液滴の組に ついて，条件式 (15) を満たす場合には，一方の液滴を 合体後の状態に変更し，他方の液滴を消滅させる。

\section{4. 実 験 方 法}

本研究では，計算モデルを同定するために単一液滴 の幾何形状や力学的特性を計測する基本実験と, 計算 結果の妥当性を検証するために計算と同様の条件に招 ける液滴群の様子を觀測する検証実験を行う。なお， 基本実験における空気力の計測および検証実験には, 三菱自動車工業株式会社の三次元煙風洞を使用した。

基本実験では，注射器で撥水性表面上に所定の質量 の液滴を形成し，その液滴を物体表面に移して各実験 を行う。また，ビデオカメラで撮影した連続画像を用 いて, 液滴の幾何形状や運動を計測する.

検証実験では，風洞に平板及び物体を設置すると共 に，その上流に設置した噴霧器から液体を噴霧した状 態で風洞を作動させて，液滴群を含む気体を物体に向 かって流す，そして，物体表面の液滴群をビデオカメ ラで撮影し，その状態を観察する。

\section{5. 実 験 条 件}

両実験で使用する物体の材質は米松の集成材であり， この表面を磨いた後にアクリルウレタン樹脂塗料を塗 布する，また，液滴をつくる液体には水道水を用いる。

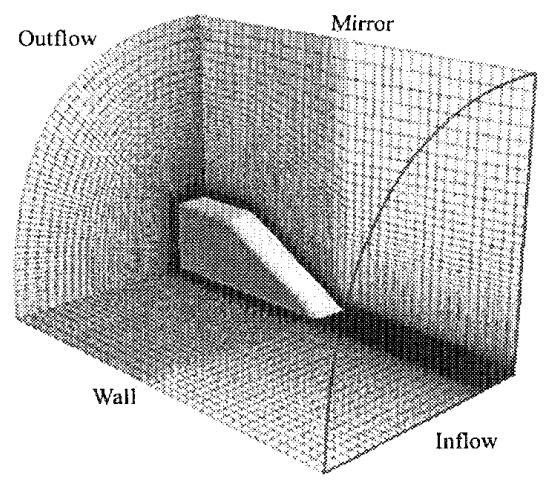

Fig. 4 Computational Grid

検証実験に打いて，物体の形状は，図 1 に示すよう に，底辺 $680 \mathrm{~mm}$, 高さ $250 \mathrm{~mm}$, 底辺と斜辺の成す角が 前側 $30 \mathrm{deg}$, 後側 $90 \mathrm{deg}$ の台形を側面とし, 幅 $250 \mathrm{~mm}$ の柱状体とする。 また，前側斜面と側面または上面が 成す角部は，半径 $10 \mathrm{~mm}$ の円弧によって滑らかに結合 される。物体は水平な平板上に置かれ，その平板の前 縁は，物体の前縁に平行で $500 \mathrm{~mm}$ 離れた位置にある。

気流は物体前縁に垂直で水平な方向から $20 \mathrm{~m} / \mathrm{s}$ で流

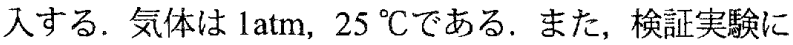
おいて，気流と共に流入する液滴が物体前面に付着す る量の涻測值は，前面中央付近で約 $4 \ell / \mathrm{min} \cdot \mathrm{m}^{2}$ である。

\section{6. 計 算 条 件}

気体流れ場の計算に用いた計算格子を図 4 に示す. 格子数は $90 \times 90 \times 90=729,000$ である。また，物体の 形状は実験と同じである。ただし，問題の対称性を仮 定して，物体中央を通る対称面から向かって左半分の みを計算対象とし，対称面には鏡面条件を与える。上 流側の境界には，実験と同じ流入条件を与える。また， 側方および下流側の境界には流出条件を与える。

物体の材質や表面性状および液体の物性の条件はパ ラメータ同定の結果として考慮される，液体の密度は $1.0 \mathrm{~g} / \mathrm{cm}^{3}$ とする.

物体前面に追加する液滴の条件について，検証実験 時における観察結果を参考として，対称面からの距離 が $100 \mathrm{~mm}$ 以下で高さが $225 \mathrm{~mm}$ 以下の範囲に，平均 付着量 $4 \ell / \mathrm{min} \cdot \mathrm{m}^{2}$ でランダムに液滴が付着すると仮定 する，また，液滴の粒径分布である式(19)のパラメー タは, 実験で用いた噴霧器の仕様を参考として, $D_{0}=$ $1.0 \mathrm{~mm}, n=2.0$ とする. なお, 液滴径の最大值, 最小 值をそれぞれ $D_{\max }=3.0 \mathrm{~mm}, D_{\min }=0.5 \mathrm{~mm}$ に設定す る、最大值は，計算の利便性を目的とした值であり， 元の累積質量分布で $99.99 \%$ に相当する. 一方，最小 值は，計算領域に存在する液滴の総数を減らすための 值であり，元の累積質量分布で $20 \%$ に相当する．こ の妥当性については 8.1 節で述べる. 


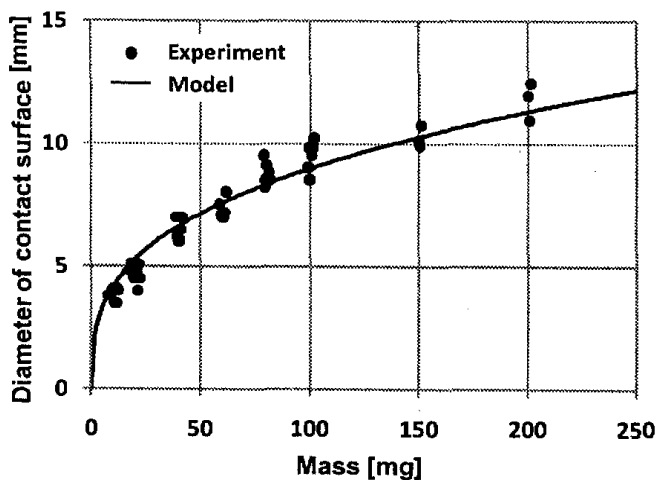

Fig. 5 Diameter of contact surface

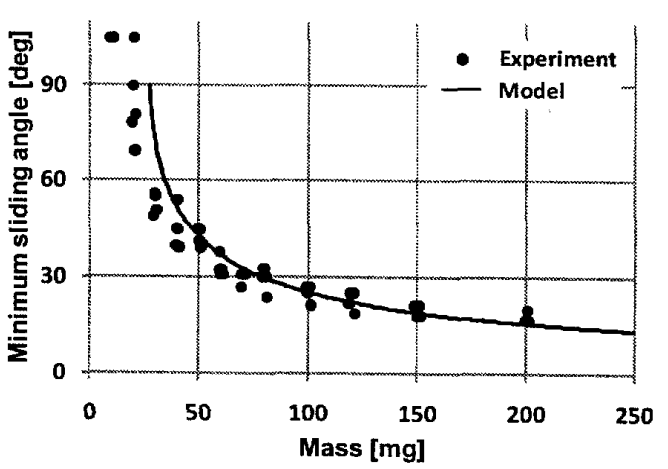

Fig. 6 Minimum sliding angle

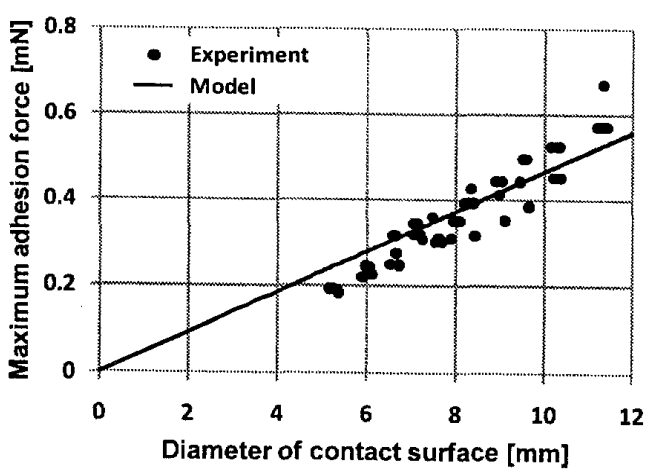

Fig. 7 Maximum adhesion force

\section{7. モ デ同定}

本章では, 単一液滴の幾何形状や力学的特性を計測 した基本実験の結果，および，その結果を用いて各計 算モデルのパラメータを同定した結果を示す.

$7 \cdot 1$ 液滴の形状 水平な物体表面の上に所定の 質量の液滴を置き, その接触面の平均径を計測した。 その結果を図 5 に点で示す.

この実験結果に対して, 式 (5) の仮定の下で最小二 乗法によって接触角 $\theta$ の值を求めると， $\theta=64 \mathrm{deg}$ が 得られる.この值を用いた式 (5) の関係を図 5 に曲線 で示す. 図を見ると，実験結果と計算モデルの傾向が 一致していることが分かる。

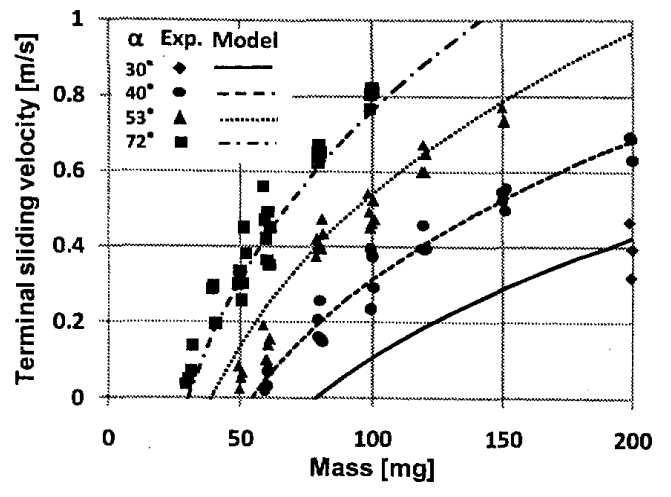

Fig. 8 Terminal sliding velocity

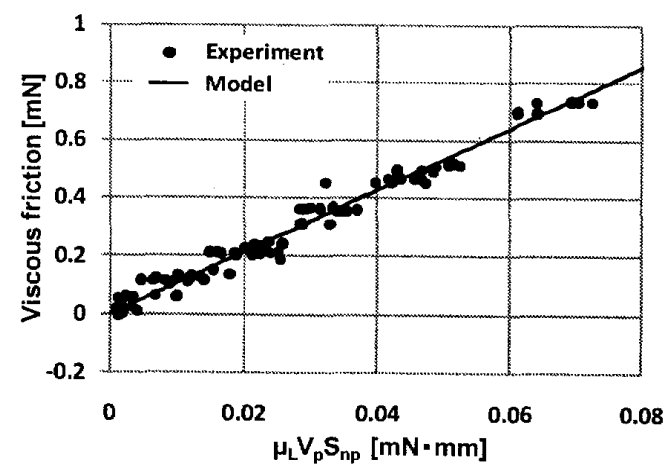

Fig. 9 Viscous friction

$7 \cdot 2$ 付着力 所定の質量の液滴が置かれた物体 表面を徐々に傾けていき, 液滴が転落を開始する表面 の傾斜角である転落角 $\alpha$ を計測した．その結果を図 6 に点で示す．図中で転落角が 90degよりも大きい点は, 表面を垂直にしても液滴が転落しないことを表す。

液滴の転落開始時, 次の力学的関係が成り立つ.

$$
f_{S, \max }=m_{p} g \sin \alpha
$$

この関係式抢よび式 (5) によって，図 6 の実験結果を 接触面直径 $D_{p}$ と最大付着力 $f_{S, \text { max }}$ の関係に換算した 結果を図 7 に点で示す.

この結果に対して，式(9)の仮定の下で最小二乗法に よって比例係数 $\gamma$ の值を求めると, $\gamma=1.5 \times 10^{-2} \mathrm{~N} / \mathrm{m}$ が得られる．この值を用いた式(9)の関係を図 7 に曲 線で示す。また，これを質量 $m_{p}$ と転落角 $\alpha$ の関係に 換算した結果を図6に曲線で示す，図を見ると，実験 結果と計算モデルの傾向が一致していることが分かる.

$7 \cdot 3$ 粘性摩擦力 転落角よりも大きい所定の傾 斜角 $\alpha$ で保持された物体表面の上に所定の質量の液 滴を置き，最終的に一走となる液滴の転落速度である 終速度 $V_{p}$ を計測した. その結果を図 8 に点で示す.

液滴の定速転落時, 次の力学的関係が成り立つ.

$$
f_{V}+f_{S, \max }=m_{p} g \sin \alpha
$$




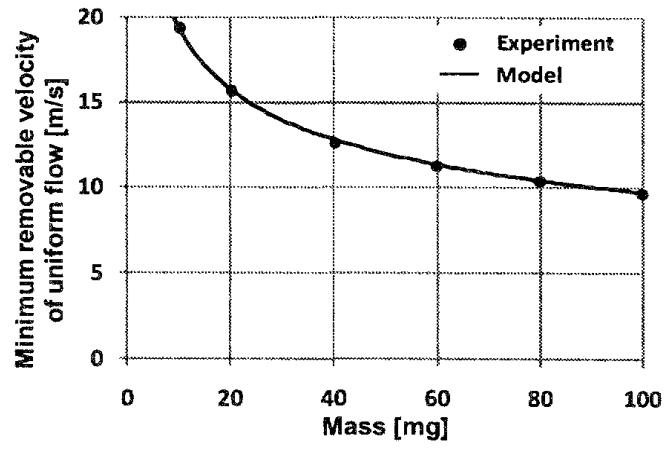

Fig. 10 Minimum removable velocity of uniform flow

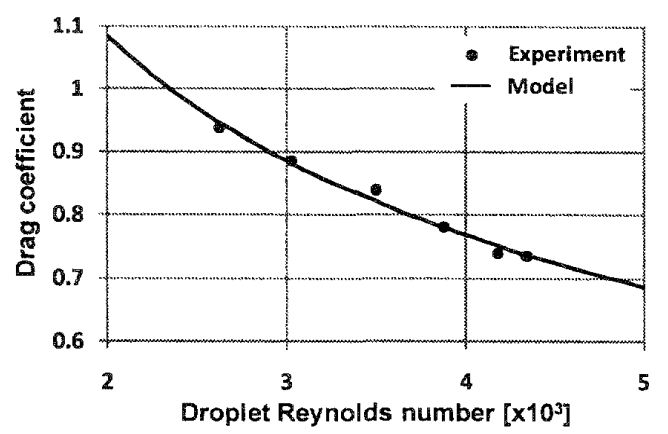

Fig. 11 Drag coefficient

この関係式と式 (6) および式 (9) によって，図 8 の実 験結果を積 $\mu_{L} V_{p} S_{n p}$ と粘性摩擦力 $f_{V}$ の関係に換算し た結果を図 9 に点で示す.

この結果に対して，式(10) の仮定の下で最小二乗法 によって係数 $\lambda$ を求めると， $\lambda=9.4 \times 10^{-5} \mathrm{~m}$ が得ら れる．この值を用いた式(10) の関係を図 9 に曲線で示 す。また，これを各傾斜角 $\alpha$ に扔るる質量 $m_{p}$ と終速 度 $V_{p}$ の関係に換算した結果を図 8 に曲線で示す。図 を見ると，実験結果と計算モデルの傾向が一致してい ることが分かる。

7.4 空気力 風洞内で一様流に平行になるよう に保持された物体表面の上に所定の質量の液滴を置き， 一様流の速度を徐々に増加させたときに液滴が移動を 開始する一様流速度である最小除去一様流速 $V_{A}$ を計 測した. その結果を図 10 に点で示す。なお，液滴は 平板前縁から $30 \mathrm{~cm}$ の位置に置かれる.

液滴の移動開始時, 次の力学的関係が成り立つ.

$$
f_{A}=f_{S, \max }
$$

この関係式と式(9), 式(11)，式(13)，および, 気流の 境界層の速度分布を与えるブラジウスの解によって, 図 10 の実験結果を液滴レイノルズ数 $R_{p}$ と抗力係数 $C_{D}$ の関係に換算した結果を図 11 に点で示す.

この結果に対して，式 (13)の仮定の下で最小二乗 法によってパラメータ $C_{D 0}, m$ を求めると, $C_{D 0}=67$,

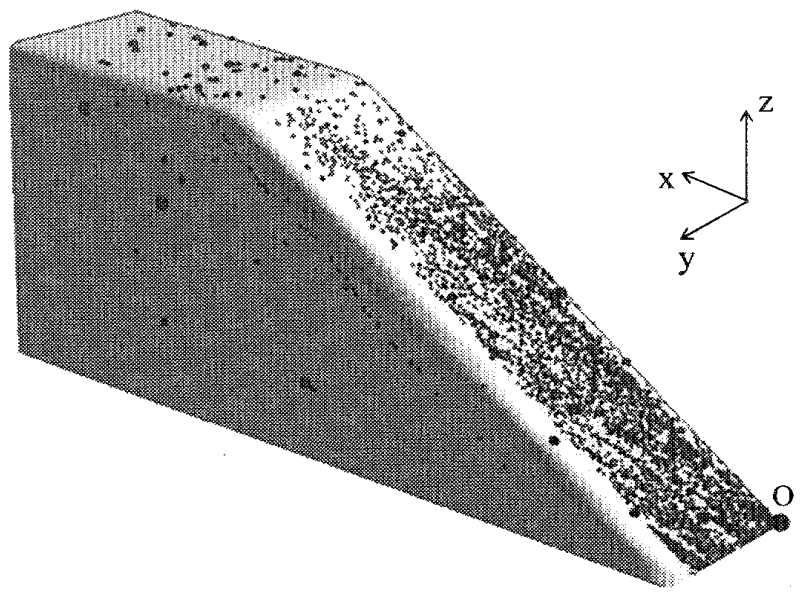

Fig. 12 Distribution of droplets on the object surface

$m=0.63$ が得られる.この值を用いた式 (13)の関係 を図 11 に曲線で示す. また，これを質量 $m_{p}$ と最小除 去一様流速 $V_{A}$ の関係に換算した結果を図 10 に曲線で 示す．図を見ると，実験結果と計算モデルの傾向が一 致していることが分かる.

\section{8. 計 算 結 果}

前節で求めた各パラメータを用いて計算した結果と して, 液滴の付着を開始してから 5 秒後に扔ける液滴 群の様子を図 12 に示す．物体の前方斜面に付着した 液滴は，気流によって，物体表面を伝わりながらその 側方や上方へ移動する。

8.1 前方斜面上の液滴群の運動 前方斜面近傍 における気流の流線を図 13(a) に示す．流線は，物体 前縁から $10 \mathrm{~mm}$ 扣よび表面から $1 \mathrm{~mm}$ 離れた位置を起 点とする. 図を見ると，物体の対称面から離れた位置 では，物体側面に対して垂直外向きの気流速度成分が 大きくなることが分かる．この気流による空気力が一 部の液滴を側面へ運ぶ。なお，速度の大きさは，斜面 の境界近傍を除いてほぼ一様である、また, 気流の境 界層厚さは，斜面の中央部で約 $2 \mathrm{~mm}$ である。

前方斜面上の液滴群の分布について, 液滴群の付着 が開始してから 0.30 秒後, 0.55 秒後, 0.80 秒後の分 布を図 13(b)，(c)，(d)にそれぞれ示す。

図 13(b) に示すように, 液滴群の付着開始直後から 一定時間，液滴群は一様にランダムな分布を示す。こ の時点では，斜面境界近傍の一部の液滴を除いて，液 滴は静止状態を維持する．これは，付着する液滴が小 さいためであり，具体的には以下の二つの要因による.

第一に，液滴の径が小さくなると，液滴を拘束する 付着力が液滴を駆動する空気力に比べて相対的に大き くなる，これは，付着力が液滴径に比例するのに対し， 


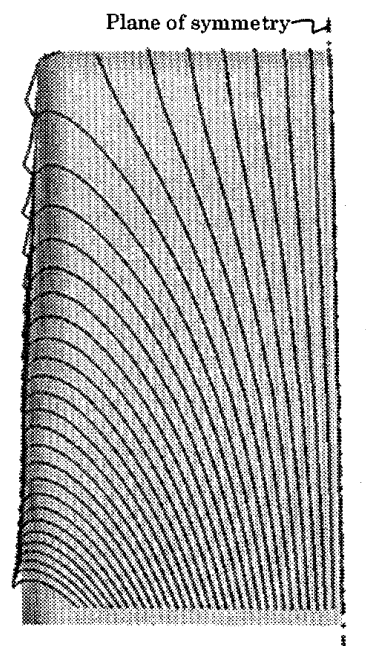

(a) Air streamlines over the surface

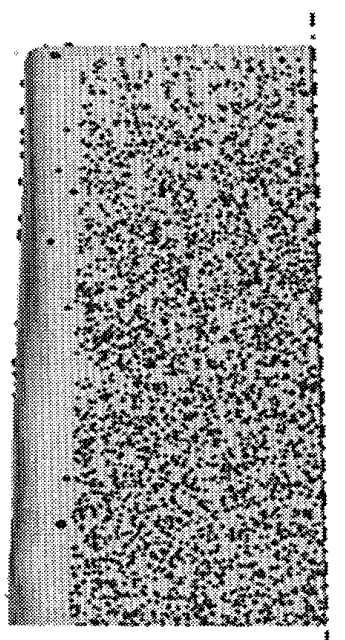

(b) Droplet distribution at $0.30 \mathrm{sec}$

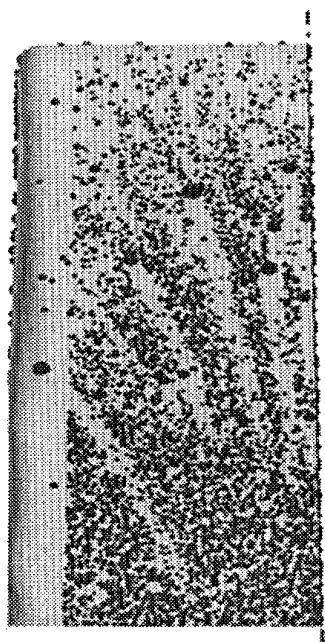

(c) Droplet distribution at $0.55 \mathrm{sec}$

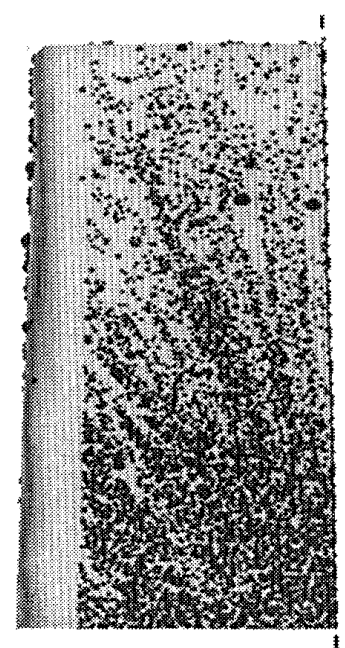

(d) Droplet distribution at $0.80 \mathrm{sec}$

Fig. 13 Air streamlines over the front surface and droplet distributions on the front surface

液滴を駆動する空気力が液滴径の二乗に比例するため である，第二に，液滴の径が小さくなると，液滴が境 界層厚さに対して相対的に低くなった結果, 液滴に向 かう気流速度が実質的に低下するため, 十分な空気力 が得られない. 例えば, 液滴径分布の基準径 $D_{0}=1 \mathrm{~mm}$ の液滴について，付着状態での高さは $0.5 \mathrm{~mm}$ であり, 気流の境界層に埋もれる. 以上の結果は, 図 10 に示す 空気力を同定する基本実験の結果でも明らかであり, 液滴が小さいほど, それを動かすのに必要な気流速度 は高くなる．ただし，前方斜面上では重力も作用する ため, 液滴が大きすぎる場合にも液滴は移動しない, もしくは，気流に逆らって転落する．

液滴の付着を続けると, 図13(c) に示すように, 大き な液滴が発生する．静止した液滴は，自身の存在する 位置に新たに付着する液滴と合体し，徐々に大きくな る. そして，その大きさがある閾値を超えると, 液滴 は斜面を登り始める. そのとき, 液滴は自身の進行方 向上にある他の液滴と合体するため, 液滴は移動しな がら成長を続け，加速しながら移動する，また，その 液滴が通過した跡では, 新たな液滴が付着するまでの 一定時間, 液滴が消滅する。この結果として, 図 13(c) に示すような分布が現れる.

なお，液滴径分布において非常に小さな液滴が気流 によって物体表面に付着する可能性は低く，また仮に 付着しても静止状態で大きな液滴の糧になる。した がって、計算コスト低減のために大きく設定する必要 のある最小粒径について, 計算結果への影響は小さい.

さらに所定時間経過すると，図 13(d)に示すように， 大きな液滴が通過した跡が新たに付着した液滴によっ て消されるのと共に, 別の箇所で成長した液滴が上方

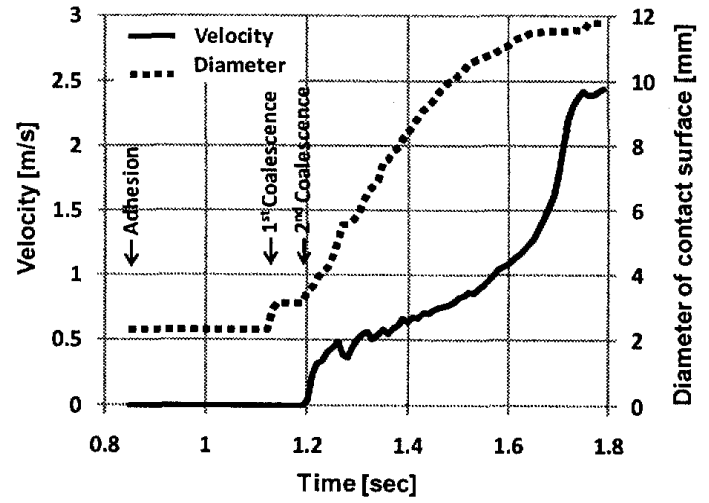

(a) Velocity and contact surface diameter

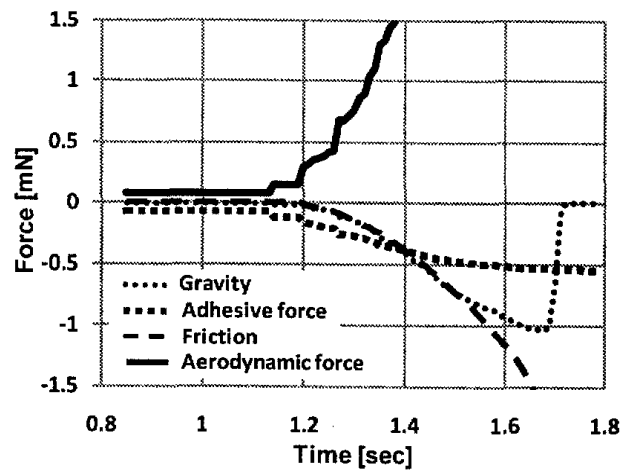

(b) Tangential forces

Fig. 14 Time history of velocity, diameter of contact surface, and tangential forces of a droplet

に向かって加速する，その後は，このような大きな液 滴の上昇運動が，ランダムな位置で間欠的に繰り返さ れる，そして，上昇する液滴の一部は気流によって側 方に流される。

以上に述べた液滴の成長扔よび運動のメカニズムを 


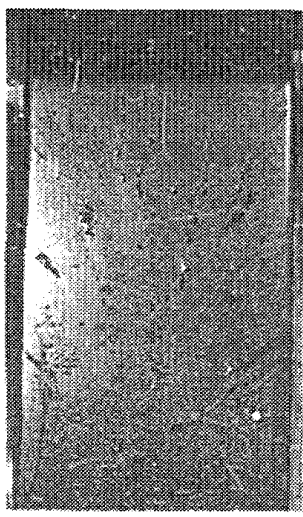

(a) Overall view

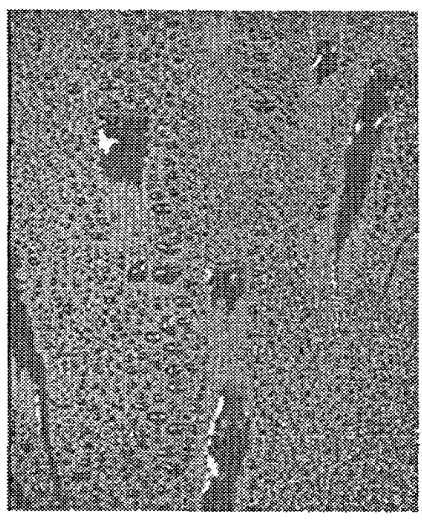

(b) Enlargement
Fig. 15 Droplets distribution on the front surface in experiment

示す例として，ある液滴の速度と付着面直径の時間履 歴を図 14(a)k，面内力の各成分の時間履歴を図 14(b) に，それぞれ示す。この液滴は，液滴群の付着が開始 されてから 0.85 秒後に前方斜面に付着する. この時 点では液滴が小さく，重力と付着力が空気力を打ち消 す結果, 液滴は静止状態にある. その後, 1.13 秒後と 1.20 秒後に飛来した二つの液滴との合体によって, 液 滴が所定の大きさに達すると, 空気力が重力と付着力 に勝り，液滴は上昇運動を開始する，そして，液滴は 合体を繰り返して成長しながら加速し，物体上面に達 する。なお，上昇運動時に抢ける複数回の速度の微減 は，合体相手の液滴が静止していることによる.

検証実験の結果について，前方斜面に分布する液滴 群の様子を図 15(a) に示す．また，別の時刻における 前方斜面の一部を拡大したものを図 15(b) に示す．図 15(a) を見ると，比較的大きな液滴が上方および側方 に向かって移動することが分かる。また，図 15(b) を 見ると，表面上に分布した多数の小さな液滴を大きな 液滴が取り込みながら移動し，その跡には液滴が存在 しない様子が分かる.これらの観測結果は，計算結果 と定性的に一致する。，一方，計算モデルでは考慮して いない液滴の変形が実際には顕著に現れる。大きな液 滴が高速で表面上を移動するとき，液滴は進行方向に 大きく伸長し，場合によっては分裂する．このような 現象を捉えて計算精度をより高めるためには，液滴の 変形や分裂を考慮するモデルを追加する必要がある.

\section{2 側面上の液滴群の運動 側面近傍に扔ける} 気流の速度べクトル分布を図 16(a) に示す．図を見る と, 前方斜面から少し下方の部分で, 斜面に沿って速 度が非常に遅い部分があることが分かる. 以降，この 領域を死水域と呼ぶ，そして，死水域の下方では，そ の死水域に沿うような速度場が形成され，大きな鉛直

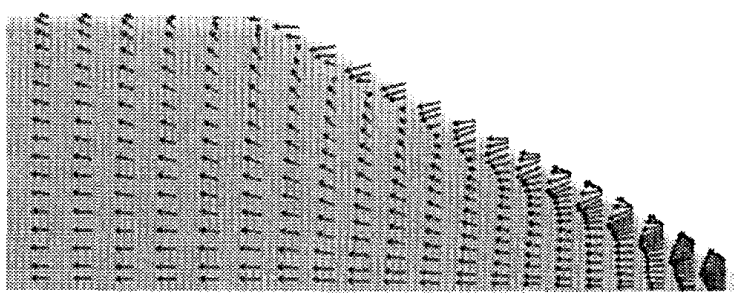

(a) Air velocity vectors over the surface

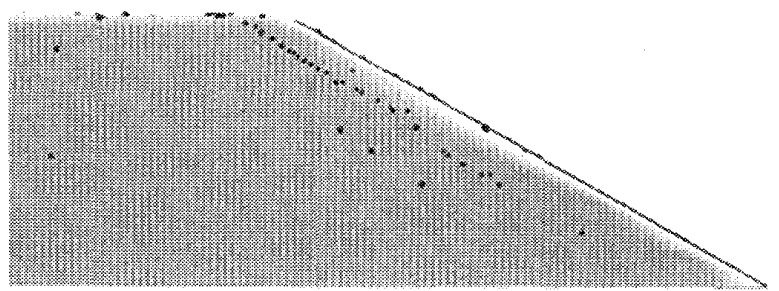

(b) Droplet distribution on the surface at $0.30 \mathrm{sec}$

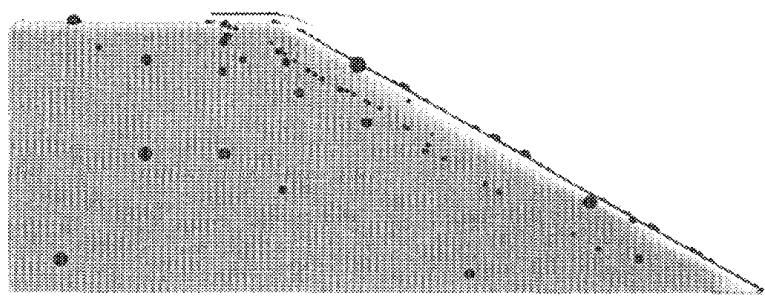

(c) Droplet distribution on the surface at $0.60 \mathrm{sec}$

Fig. 16 Air velocity vectors over the side surface and droplet distributions on the side surface

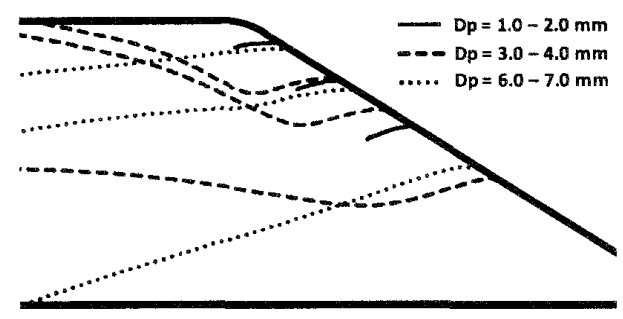

Fig. 17 Droplet paths on the side surface

上向きの速度成分が存在する．これは，前方斜面から 側方に流れる気流が，前方斜面と側面をつなぐ角の部 分で剥離し，それによって発生する渦の負圧が流れを 上方に引き上げることで発生する。

側面上の液滴群の分布について，前面への液滴群の 付着が開始してから 0.30 秒後, 0.60 秒後の分布を図 16(b)，(c)にそれぞれ示す. 図16(b)に示すように，早 い時間に前方斜面から側面に移動する比較的小さな液 滴は，死水域に滞留する．これは，付着する液滴が小 さく, かつ, 気流速度の主流方向成分が小さいためで あり, 空気力と重力を打ち消すような付着力が液滴に 作用している. その後, 前方斜面では次第に大きな液 滴が発生するようになり，図16(c) に示すように，そ の一部が前方斜面から側面に流れ込む. 


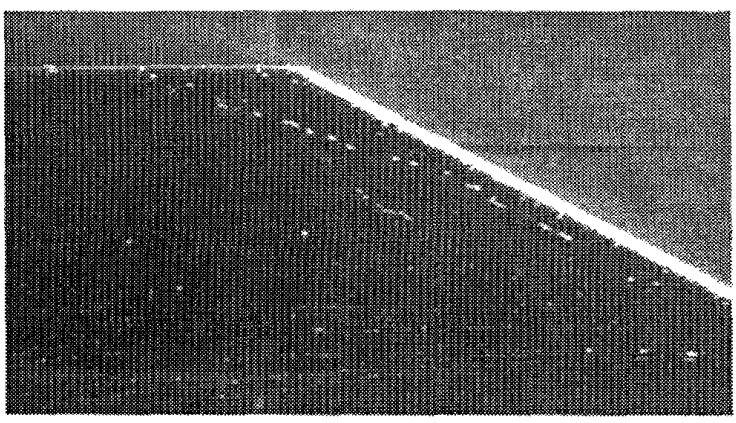

Fig. 18 Droplets distribution on the side surface in experiment

側面上における代表的な液滴の軌跡を図 17 に示す. 図 17 の実線で示されるように，流れ込んだ液滴が比 較的小さい場合, 初期に流入した液滴と同様に死水域 に滞留する.また，図 17 の破線で示されるように, 流 れ込んだ液滴が中程度の大きさである場合, 死水域に 滞留した液滴を合体によって取り込みながら，下流側 へ移動する.このとき, 死水域の下に存在する上昇気 流による空気力が重力よりも大きいため, 液滴は上昇 し，その一部は物体の上面へ移動する。一方，図 17 の点線で示されるように, 流れ込んだ液滴が比較的大 きい場合, 液滴径の三乗に比例する重力が液滴径の二 乗に比例する空気力よりも支配的になり, 液滴は下降 しながら後方へ流れ去る。

検証実験の結果について, 側面に分布する液滴群の 様子を図 18 に示す．図を見ると，前方斜面から少し 下方の部分で, 複数の液滴が滞留している様子が分か る. また，これらの液滴の一部が合体によって成長し た後に上昇して上面へ移動する様子や，上面から遠い 液滴の一部がほぼ水平な角度で後方へ流れる様子が観 测された.この観測結果は，計算結果と定性的に一致 する. 一方, 計算モデルでは考慮していない液滴の変 形が側面でも現れる場合がある，具体的には，死水域 に滞留した液滴は一列に連なるように合体し, 線状に 上面へ流れ込む現象が間欠的に発生する．このような 現象を捉えて計算精度をより高めるためには, 液滴の 変形や分裂を考慮するモデルを追加する必要がある.

\section{9. 結言}

固体表面に付着した液滴群が空気力によって移動す る現象を予測する数值シミュレーションの方法を提案 した. 具体的には，個々の液滴を追跡するラグランジュ 的手法を用い, 液滴に作用する力の評価や液滴の粒径 分布および合体の考慮を簡単に実行できる方法を示し た.また，簡単な基本実験によってモデルのパラメー タを同定する方法を示した. 本提案方法は, 物理的な
解釈が容易であり，かつ，比較的低コストで計算でき る実用性の高いシミュレーション方法である.

そして，提案した方法を用いて，気流にさらされた 三次元台状物体の表面に付着した液滴群のシミュレー ションを行った. 物体前面に付着した液滴は, 後に付 着する液滴と合体を繰り返して所定の大きさまで成長 すると，上方への移動を開始する．移動した液滴の一 部は前面から側面に移動する．このとき，比較的小さ い液滴は気流の剥離により生じる気流速度の低い領域 に帯留する一方, 中程度の液滴は上昇しながら, 比較 的大きい液滴は下降しながら，それぞれ下流側へ移動 する.これらの結果は，実験による観測結果と定性的 に一致した，これにより，提案したシミュレーション 方法の基本的な妥当性が確認された。

\section{文献}

(1) Nakagawa, K., Kohri, I. and Yanagimoto, K., Aerodynamic Research of Door Mirror, Automotive Technology (in Japanese), Vol.39, No.3 (1985), pp.252-259.

(2) China, H. and Yoshida, M., Application of Flow Visualization Technique to Car Development, Automotive Technology (in Japanese), Vol.51, No.4 (1997), pp.32-36.

(3) Nakajima, A., Suzuki, S., Kameshima, Y., Yoshida, N., Watanabe, T. and Okada, K., Sliding Mode Transition of Water Droplet on the Silicon Surface Coated with Octadecyltrichlorosilane, Chemistry Letters, Vol.32, No.12 (2003), pp.1148-1149.

(4) Zhang, F. Y., Yang, X. G. and Wang, C. Y., Liquid Water Removal from a Polymer Electrolyte Fuel Cell, Journal of Electrochemical Society, Vol.153, No.2 (2006), pp.225232.

(5) Dukowicz, J. K., A Particle-Fluid Numerical Model for Liquid Sprays, Journal of Computational Physics, Vol.35 (1980), pp.229-253.

(6) Wolfram, E. and Faust, R., Liquid Drops on a Tilted Plate, Contact Angle Hysteresis and the Young Contact Angle, Wetting, Spreading and Adhesion, (1978), pp. 213-222.

(7) Furmidge, C. G. L., Studies at Phase Interfaces I. The Sliding of Liquid Drops on Solid Surfaces and a Theory for Spray Retention, Journal of Colloid Science, Vol.17 (1962), pp.309-324.

(8) Sakai, M., Song, J. H., Yoshida, N., Suzuki, S., Kameshima, Y. and Nakajima, A., Direct Observation of Internal Fludity in a Water Droplet during Sliding on Hydrophobic Surfaces, Langmuir, Vol.22 (2006), pp.4906-4909.

(9) Mugele, R. A. and Evans, H. D., Droplet Size Distribution in Sprays, Industrial and Engineering Chemistry, Vol.43 (1951), pp.1317-1324. 